\title{
Non-Standard Work and Limits on Freedom of Association: A Human Rights-Based Approach
}

\author{
VALERIO DESTEFANO*
}

\begin{abstract}
The debate on how to adjust existing regulation to keep pace with the rise and spread of the non-standard workforce worldwide has mainly concentrated on individual employment law. This article means to draw attention to some collective labour regulation issues that have a significant impact on the labour protection of non-standard workers. Without subscribing to the idea that the standard employment relationship is an outmoded model of regulation, this article argues that some existing restrictions on collective rights are failing to keep pace with transformations of labour markets that occurred in recent decades and in particular with the growth in the number of non-standard workers. Consequently, these workers are legally or practically denied access to the meaningful exercise of collective rights. Some of these restrictions, such as antitrust bans on collective bargaining, regulations imposing strike ballots, limitations of secondary action and the distinction between political and economic strikes, are called into question since they disproportionately affect non-standard workers and are at odds with the recognition of collective rights, and in particular the right to strike, as human rights.
\end{abstract}

*International Labour Office and Bocconi University, email: valerio.destefano@unibocconi. it. The opinions expressed in this article are the author's only and do not necessarily represent the position of the International Labour Office or the International Labour Organisation. I wish to thank the anonymous referees, Simon Deakin, Janine Berg, Judy Fudge, Tonia Novitz, Giovanni Orlandini and Rochelle le Roux for their precious comments and feedbacks on this article. The usual disclaimers apply. This article stems from the discussions hold during the two presentations of the book Laws against Strikes. The South African Experience in an International and Comparative Perspective (Milano: Franco Angeli, 2015) edited by B. Hepple, R. le Roux and S. Sciarra. The presentations were hold during the 2 nd Conference of the Labour Law Research Network in Amsterdam in June 2015 and the ISLSSL (International Society for Labour and Social Security Law) 21st World Congress 2015 in Cape Town in September 2015. I am extremely grateful to Silvana Sciarra and Rochelle le Roux for inviting me to discuss this seminal book in those occasions and to all the participants to those presentations. This article is dedicated to the memory of Professor Sir Bob Hepple QC. 


\section{INTRODUCTION}

This article deals with the collective labour law aspects of the labour protection of non-standard workers. It aims at contributing to advance the debate regarding the need to adapt existing regulatory frameworks and policy strategies in order to confront the growth of the non-standard workforce in recent decades. Arguably, a vast part of this debate has concentrated on issues related to individual employment law and social security. ${ }^{1}$ Instead, less attention has been given to the questions that the emergence of nonstandard work in modern labour markets poses regarding the regulation of collective rights. $^{2}$

This article argues that many of the existing limitations and restrictions to freedom of association, the right to collective bargaining and the right to strike disproportionately affect non-standard workers. Indeed, in some cases, these restrictions go as far as denying access of non-standard workers to collective rights. This article intends to reorient part of the current legal and policy debate on non-standard work towards its collective dimensions. It provides examples of limitations that hamper the full exercise of freedom of association in a way that fails to keep pace with the overall changes that occurred in labour markets and societies in recent decades. It also examines

\footnotetext{
${ }^{1}$ Extensive references and data are provided in ILO, Non-Standard Employment around the World. Understanding Challenges, Shaping Prospects (Geneva: ILO, 2016). The scientific literature on this debate is extremely vast: see A. Supiot, Beyond Employment. Changes in Work and the Future of Labour Law in Europe (Oxford: Oxford University Press, 2001); G. Bosch, 'Towards a New Standard Employment Relationship in Western Europe' (2004) 42 British Journal of Industrial Relations 617-36; L. Vosko, Managing the Margins Gender, Citizenship, and the International Regulation of Precarious Employment (Oxford: Oxford University Press, 2010); M. Freedland and N. Kountouris, The Legal Construction of Personal Work Relations (Oxford: Oxford University Press, 2011); J. Fudge, S. McCrystal and K. Sankaran, Challenging the Legal Boundaries of Work Regulation (Oxford: Hart, 2012); K. V. W. Stone and H. Arthurs (eds), Rethinking Workplace Regulation: Beyond the Standard Contract of Employment (New York: Russell Sage Foundation, 2013); Z. Adams and S. Deakin, 'Institutional Solutions to Inequality and Precariousness in Labour Markets' (2014) 52 British Journal of Industrial Relations 779-809; J. Rubery, 'Reregulating for Inclusive Labour Markets', ILO Conditions of Work and Employment Series Working Paper No. 65 .

${ }^{2}$ See, however, A. C. L. Davies, “Half a Person”: A Legal Perspective on Organizing and Representing "Non-Standard" Workers' in A. Bogg and T. Novitz (eds), Voices at Work. Continuity and Change in the Common Law World (Oxford: OUP, 2014); A. J. S. Calvin, 'Organizational Primacy: Employment Conflict in a Post-Standard Contract World' in K. V. W. Stone and H. Arthurs (n.1) and the contributions published in J. Holdcroft, 'Meeting the Challenge of Precarious Work: A Workers' Agenda' (2013) 5 International Journal of Labour Research 41-57.
} 
whether these limitations are still suitable to govern current labour markets or whether they have become unreasonably burdensome for the time being. In doing so, constant reference is made to a legal development that has occurred in relatively recent times, namely the increasing recognition of labour rights as human rights and, within this framework, the evolution of the rationale of the right to strike 'from being a weapon in collective bargaining into an individual human right', remarked by Professor Sir Bob Hepple QC in one of his last works. ${ }^{3}$ In this perspective, this article argues that existing regulations of collective rights, especially, the right to strike, should be reassessed to investigate whether they are compatible with the 'human right' status of these rights and whether they are necessary, in democratic societies, to ensure the fulfilment of other basic needs and, in particular, the exercise of other human rights.

Section 2 discusses non-standard forms of employment as recently described by the International Labour Office (ILO) and argues that reference to the distinction between 'standard' and 'non-standard' work is still meaningful. This is because the standard employment relationship (SER) is still a central institution in modern labour markets both from an empirical and regulatory standpoint and that this distinction is also useful to investigate the endogenous role of regulation, and also collective labour regulation, in the growth and spread of non-standard work arrangements. Section 3 discusses practical and legal obstacles that affect non-standard workers in effectively exercising freedom of association and related collective rights, including the negative implications of antitrust regulation in this respect. Section 4 moves from the consideration that labour rights, especially the right to strike, can be classified as human rights and that this classification has a particular significance in assessing the existing restrictions to collective rights that may disproportionately affect non-standard workers. The other sections specifically analyse examples of these restrictions. Section 5 discusses the obstacles that regulation regarding strike ballots may pose to non-standard workers. Section 6 argues that existing standards on secondary action have grown outmoded due to the disintegration of the vertical firm and the related 'fissurisation' of the workplace that occurred in the last decades. Section 7 argues that the distinction between political and economic strikes fails to keep pace with policies that materially affect non-standard

${ }^{3}$ B. Hepple, 'The Freedom to Strike and its Rationales' in B. Hepple, R. le Roux and S. Sciarra (eds), Laws against Strikes. The South African Experience in an International and Comparative Perspective (Milano: Franco Angeli, 2015). 
workers such as those aimed at shifting the focus of labour protection from the enterprise to labour markets as a whole. Section 8 provides a conclusion.

\section{NON-STANDARD WORK, THE ENDURING ROLE OFTHE SER ANDTHE ENDOGENEITY OF REGULATION IN THE GROWTH OF NON-STANDARD ARRANGEMENTS}

The ILO has recently described non-standard forms of employment to 'include, among others, fixed-term contracts and other forms of temporary work, temporary agency work and other contractual arrangements involving multiple parties, disguised employment relationships, dependent self-employment and part-time work' This open and non-exhaustive description conveys a rather comprehensive picture of the various possible non-standard types of employment in formal economies across the globe. In this article, I use the term 'non-standard' work and use this description as point of reference. This is not only because they were both adopted in the Conclusions of an ILO meeting of national experts selected on a tripartite basis and endorsed by the Governing Body of the ILO,${ }^{4}$ and therefore met a significant consensus at the international level, but also because the term non-standard work is theoretically preferable to other terms that are often used to refer to similar phenomena. For instance, one of the terms most frequently used as counterparts of 'non-standard employment', 'precarious work', as suggestive as it is arguably extends much beyond the borders of non-standard work. ${ }^{5}$ Moreover, not every non-standard worker is precarious, since there could be non-standard work contracts that, nonetheless, provide sufficient stability of employment and income, such as some form of fixed-term, agency work or part-time contracts.

It could also be argued that, by referring to "non-standard employment', one acquiesces to a SER-centric vision of labour markets, one that is inevitably becoming outmoded as the SER grows displaced by other forms of work ${ }^{6}$ and social norms traditionally associated with the SER

${ }^{4}$ ILO, Governing Body, 323rd Session, Conclusions of the Meeting of Experts on NonStandard Forms of Employment (Geneva: ILO, 12-27 March 2015) 50.

${ }^{5}$ On this point, also for comprehensive references to the debate, see N. Kountouris, 'The Legal Determinants of Precariousness in Personal Work Relations: A European Perspective' (2013) 34 Comparative Labor Law \& Policy Journal 21-46; M. Paret, 'Precarious Class Formations in the United States and South Africa' (2016) 89 International Labor and Working-Class History 84-106. See also Section 3 below.

${ }^{6}$ See, for instance, K. V. W. Stone, 'The Decline in the Standard Employment Contract: A Review of the Evidence' in K. V. W. Stone and H. Arthurs (n.1). 
are decreasing. ${ }^{7}$ This objection, however, would be at odds with empirical evidence that suggests that the SER remains the dominant form of employment in industrialised countries and is far from disappearing in numerical terms. ${ }^{8}$ Moreover, notwithstanding the removal or weakening of regulatory barriers against recourse to non-standard forms of work, the SER maintains its role as a benchmark of employment regulation in most jurisdictions of the world. ${ }^{9}$ Nor should it be taken for granted that the growth of non-standard work is a 'natural' and irreversible economic phenomenon that is independent from the relevant regulatory framework. Instead, it can be argued that regulation plays an endogenous role in the emergence and spread of non-standard work in different countries. ${ }^{10}$ This is not only true for regulation that allows or enlarges the scope of lawful recourse to various forms of non-standard work ${ }^{11}$ but also for regulation that promotes it as a cheap alternative to hiring standard workers. In this respect, restrictions and limitations to collective rights that disproportionately affect non-standard workers can be a prominent example. Therefore, examining these restrictions and advocating their revision does not imply an acknowledgement that the erosion of the SER in empirical terms and as a regulatory model is an irreversible, let alone completed, phenomenon. Mindful of this, the following sections highlight practical and legal obstacles that can significantly restrain non-standard workers from fully enjoying freedom of association and related collective rights.

${ }^{7}$ See L. Vosko, 'Precarious Employment and the Problem of SER-Centrism in Regulating for Decent Work' in S. Lee and D. McCann (eds), Regulating for Decent Work: New Directions in Labour Market Regulation (Basingstoke: Palgrave Macmillan, 2011).

${ }^{8} \mathrm{ILO}$ (n.1).

${ }^{9}$ G. Bosch (n.1); Z. Adams and S. Deakin (n.1).

${ }^{10}$ See S. E. Gleason (ed.), The Shadow Workforce: Perspectives on Contingent Work in the United States, Japan, and Europe (Kalamazoo, MI: Upjohn Institute for Employment Research, 2006); G. Meardi, 'The Claimed Growing Irrelevance of Employment Relations' 56 Journal of Industrial Relations 594-605; Z. Adams and S. Deakin (n.1). Z. Adams and S. Deakin, Re-regulating Zero Hours Contracts (Liverpool: The Institute of Employment Rights, 2014) provide examples of social security regulation fostering the spread of casual forms of employment. On the general endogenous role of regulation in labour markets, see S. Deakin and F. Wilkinson, The Law of the Labour Market: Industrialization, Employment, and Legal Evolution (Oxford: Oxford University Press, 2005).

${ }^{11}$ In this respect, also for a review of the economic literature, see M. Aleksynska and J. Berg, 'Firms' Demand for Temporary Labour in Developing Countries: Necessity or Strategy?', ILO Conditions of Work and Employment Series Working Paper No. 77. Using data from the World Bank Enterprise Survey of private sector firms in developing countries, the authors show how firms in countries where fixed-term contracts are prohibited for permanent tasks are statistically less likely to use temporary labour. 


\section{PRACTICAL AND LEGAL RESTRICTIONS ON FREEDOM OF ASSOCIATION FOR NON-STANDARD WORKERS:THE 'IMPLICITTHREAT' AND 'THE ANTITRUST MENACE'}

Notoriously, freedom of association is not only a right in itself but is also an 'enabling right' since its exercise may be pivotal in securing the effective exercise of other employment rights. ${ }^{12}$ Collective rights such as the right to collective bargaining and the right to industrial action are arguably some of the key instruments that can secure labour rights. In particular, the right to strike, and especially when industrial action is permitted regarding conflicts of rights, may also be a chief tool of private enforcement of labour rights. ${ }^{13}$ This is also why special attention must be paid to the right to strike when dealing with non-standard work.

Indeed, some non-standard workers, especially those in temporary work relationships, irrespective of the specific type of contract, may be reluctant to exercise some of their labour rights afraid their contract may not be renewed or prolonged at its expiry, should they do so. ${ }^{14}$ As a matter of fact, this actual or perceived 'implicit threat' of losing one's job may cause severe decent work deficits, even when the applicable regulatory framework is not unfavourable to non-standard workers. ${ }^{15}$ In this respect, the right to organise and to strike may be relevant in different and opposite ways. On the one hand, as an instrument of private enforcement of rights, they can facilitate making labour rights effective for non-standard workers without having to recur to

\footnotetext{
${ }^{12} \mathrm{On}$ the role of trade unions in ensuring enforcement and effectiveness of employment rights, see, recently, M. O'Sullivan, T. Turner, M. Kennedy and J. Wallace, 'Is Individual Employment Law Displacing the Role of Trade Unions?' (2015) 44 ILJ 222-45; on the inadequacy of individual employment law in securing effective labour protection, particularly for non-standard casual workers, see A. Pollert, 'The Unorganised Worker:The Decline in Collectivism and New Hurdles to Individual Employment Rights' (2005) 34 ILJ 217-38.

${ }^{13}$ In jurisdictions where industrial action can only be called to deal with conflicts of interests, instead, strike may however be essential in securing rights for non-standard workers such as 'stabilisation' plans: without implicating her, I owe credit to Judy Fudge for the observation on conflicts of interest.

${ }^{14}$ The ILO Supervisory Bodies highlighted how recourse to non-standard forms of work may have a detrimental impact on union rights and collective bargaining. For instance, the ILO Committee on Freedom of Association (CFA) observed how 'the renewal of fixed-term contracts for several years may alter the exercise of trade union rights': see Chile - CFA, 368th Report, Case No. 2884. See also, ILO, Committee of Experts on the Application of Convention and Recommendations (CEACR), General Survey on the Fundamental Conventions Concerning Rights at Work in Light of the ILO Declaration on Social Justice for a Fair Globalization, 2008 (Geneva: ILO, 2012) 386.

${ }^{15}$ See V. De Stefano, 'Smuggling-in Flexibility: Temporary Work Contracts and the "Implicit Threat" Mechanisms. Reflections on a New European Path' (2009) 4 Labour Administration and Inspection Programme LAB/ADMIN Working Document (Geneva: ILO).
} 
individual enforcement mechanisms such as grievance procedures or judicial claims. On the other hand, collective rights and freedom of association in itself may be particularly affected by the 'implicit threat' of losing one's job. ${ }^{16}$ This is also because, while in some jurisdictions, specific statutory remedies may be in place against dismissals originating from industrial disputes and actions or discriminatory or retaliatory dismissals against union members or workers' representatives, such remedies may be easily circumvented for nonstandard workers in temporary work, by simply not renewing or prolonging their contracts or, for 'on-demand' workers, by 'zeroing down' their working hours. This can make their position even more vulnerable, relative to standard workers, also in countries where an 'employment at will' regime is in place, since a dismissal grounded on union reasons could still amount to an unfair labour practice in those systems. ${ }^{17}$ Needless to say, as I argued before, also standard workers, particularly when ordinary dismissal protection is non-existent or scarce, may be significantly exposed to the implicit threat of losing their jobs, especially at a time when employment protection legislation is being reduced in many jurisdictions, since the mere protection against discriminatory dismissals may fall short of providing effective protection from arbitrary or discriminatory acts of the employer. ${ }^{18}$ Nonetheless, non-standard workers in temporary or on-demand arrangements can be even more exposed to such a threat, since a refusal to extend their contract or provide further work may even elude protection from discriminatory dismissal.

This may also explain the difficulties of organising non-standard workers in trade unions, ${ }^{19}$ although in some cases failure to organise them can be

${ }^{16}$ V. De Stefano (n.15); J. Holdcroft, 'Meeting the Challenge of Precarious Work: A Workers' Agenda' (n.2) 43 reports that 'the most important reason for precarious workers not joining trade unions stems from a legitimate fear of losing their job. Whenever unions conduct surveys to discover why such workers do not join unions, this is the principal reason given'. See also E. Hatton, 'Temporary Weapons: Employers' Use of Temps Against Organised Labour' (2014) 67 ILR Review 86-110.

${ }^{17}$ See, for instance, s 8(a)(3) of the United States' National Labor Relations Act, prohibiting 'discrimination in regard to hire or tenure of employment or any term or condition of employment to encourage or discourage membership in any labor organization. However, on the gaps in protecting individual bargaining in the USA, see M. Finkin, 'Employee Self-Representation and the Law in the United States' (2013) 50 Osgoode Hall Law Journal 937-64. See also MaltaCEACR, direct request, 2006.

${ }^{18} \mathrm{~V}$. De Stefano, 'A Tale of Oversimplification and Deregulation: The Mainstream Approach to Labour Market Segmentation and Recent Responses to the Crisis in European Countries' (2014) 43 ILJ 253-85, 281-2.

${ }^{19}$ It is also true that some non-standard workers, particularly those in open-ended relationships, would be exposed to the 'implicit threat' to the same extent as workers in SERs. This would be true particularly for some part-time workers and some agency workers hired by the 
attributable to frictions and reluctance of the 'standard' unionised workforce to allow non-standard workers to join or to act on their behalf. ${ }^{20}$ In several countries, however, trade unions have taken steps to secure unionisation and protection, also via collective bargaining, for non-standard workers. ${ }^{21}$ Nonetheless, 'implicit threat' effects and the potential shortcomings and loopholes in anti-retaliatory regulation can pose serious hurdles to these efforts.

Furthermore, other existing legal obstacles may hinder these trends. In some jurisdictions, non-standard workers may be prevented from joining unions $^{22}$ or unions of their choice. ${ }^{23}$ Most importantly, in some legal systems,

agency on a permanent basis. In a significant number of cases, however, these workers could still face considerable hardship in fully enjoying freedom of association and other collective rights, when, for instance, they are engaged in forms of so-called marginal part-time, whose confines with on-demand and zero-hour arrangements are increasingly blurred [see J. Messenger and P. Wallot, 'The Diversity of Marginal Part-Time', INWORK Policy Brief No. 7 (Geneva: ILO, 2015)], or when agency work is used to artificially fragment the bargaining unit (see Section 6 below). Moreover, given the triangular nature of agency work, it could be difficult for workers to obtain redress in cases of discrimination and blacklisting, see T. Novitz, 'The Redefinition of "Workers" in Times of Austerity - Implications For Freedom of Association' paper presented on 26 February 2016 at a symposium held at Trinity College Dublin on 'Emerging from Austerity: Forging Future Labour Laws in Europe'

${ }^{20}$ J. Holdcroft (n.16) discusses cases in which unions had to reform their statutes to allow non-standard workers to join and strategies to overcome hostility from existing members.

${ }^{21}$ See, for instance, R. Gumbrell-McCormick, "European Trade Unions and "Atypical" Workers' (2011) 42 Industrial Relations Journal 293-310; S. Hayter and M. Ebisui, 'Negotiating Parity for Precarious Workers', Meeting the Challenge of Precarious Work: A Workers' Agenda (n.2); K. Nakamura and M. Nitta, 'Organizing Nonstandard Workers in Japan: Old Players and New Players' in K. V.W. Stone and H. Arthurs (n.1); M. Keune, 'Trade Unions, Precarious Work and Dualisation in Europe' in W. Eichhorst and P. Marx (eds), Non-Standard Employment in Post-Industrial Labour Markets an Occupational Perspective (Cheltenham: Edward Elgar, 2015); ILO (n.1); F. L. Cooke and R. Brown, 'The Regulation of Non-Standard Forms of Work in China, Japan and Republic of Korea: A Study to the International Labour Organization', ILO Conditions of Work and Employment Series Working Paper No. 64.

${ }^{22}$ This is the case of workers with contracts shorter than 6 months in Viet Nam, pursuant to Directive 02/2004/TTR-TLD, issued by the Viet Nam General Confederation of Labour on 22 March 2004. See I. Landau, P. Mahy and R. Mitchell, 'The Regulation of Non-Standard Forms of Employment in India, Indonesia and Vietnam', ILO Conditions of Work and Employment Series Working Paper No. 63. In Poland, the judgement of the Constitutional Tribunal, 2 June 2015, declared that Art 2(1) of the Trade Unions Act of 23 May 1991 allowing only employees to establish and join a trade union was unconstitutional. According to the Tribunal, freedom of association applies to all individuals performing paid work. In 2012, the ILO CFA had requested the Government of Poland 'to take the necessary measures in order to ensure that all workers, without distinction whatsoever, including self-employed workers and those employed under civil law contracts, enjoy the right to establish and join organizations of their own choosing within the meaning of Convention No. 87': see Poland - CFA, Report No. 363, Case No. 2888.

${ }^{23}$ See Republic of Korea - CFA, Report No. 363, Case No. 2602 regarding self-employed workers in the Republic of Korea. See also K. Shin, 'Economic Crisis, Neoliberal Reforms, and 
the right to organise and the right to collective bargaining in favour of selfemployed workers can be restricted or banned for antitrust reasons. ${ }^{24}$ For instance, this may occur in the European Union, as an outcome of a recent decision of the European Court of Justice (ECJ). In 1999, the well-known Albany case granted collective bargaining of subordinated employees a partial immunity from competition law. ${ }^{25}$ The 2014 ECJ case FNV Kunsten ${ }^{26}$ regarded a collective bargaining agreement negotiated in favour of both subordinated employees and self-employed workers in orchestras. The latter were afforded a premium compensation rate. The ECJ held that collective bargaining on behalf of self-employed workers cannot be exempted from the application of competition law and therefore falls within the scope of Article 101(1) TFEU. Moreover, it is not clear what tests the ECJ would apply, when classifying work relationships for the purpose of applying antitrust rules to collective bargaining. In a paragraph of the decision, the ECJ refers to antitrust concepts, clarifying that subjects that do not 'determine independently [their] own conduct on the market' do not classify as undertakings under competition law. ${ }^{27}$ This approach would include some categories of genuine self-employed workers such as para-subordinate workers in Italy, arbeitnehmerähnliche Personen in Germany and trabajadores autónomos económicamente dependientes in Spain in the exemption from

the Rise of Precarious Work in South Korea' (2013) 57 American Behavioral Scientist 335-53. F. L. Cooke and R. Brown (n.21) also report that 'in Korea, the law allows only employees "working for the same employer" or "in the same description of work" to form a union, which limits the ability of contract workers to join unions'.

${ }^{24}$ See. C. Rubiano, 'Precarious Workers and Access to Collective Bargaining: What Are the Legal Obstacles?' Meeting the Challenge of Precarious Work: A Workers' Agenda (n.2); S. McCrystal, 'Organising Independent Contractors: The Impact of Competition Law' in J. Fudge, S. McCrystal and K. Sankaran (n.1).

${ }^{25} \mathrm{ECJ}$, Albany International BV v Stichting Bedrijfspensioenfonds Textielindustrie, 21 September 1999, C-67/96. A very recent analysis of the relationship between labour law and competition law is provided by S. McCrystal and P. Syrpis, 'Competition Law and Worker Voice: Competition Law Impediments to Collective Bargaining in Australia and the European Union' in A. Bogg and T. Novitz (n.2). See also S. Schwochau, 'The Labor Exemptions to Antitrust Law: An Overview' (2000) 21 Journal of Labor Research 535-55; P. Ichino, 'Collective Bargaining and Antitrust Laws: An Open Issue' (2001) 17 International Journal of Comparative Labour Law and Industrial Relations 185-98.

${ }^{26} \mathrm{ECJ}$, FNV Kunsten Informatie en Media, 4 December 2014, C-413/13. For an analysis of this judgement, see T. Novitz, 'The Paradigm of Sustainability in a European Social Context: Collective Participation in Protection of Future Interests?' (2015) 31 International Journal of Comparative Labour Law and Industrial Relations 243-62.

${ }^{27}$ ECJ, Confederación Española de Empresarios de Estaciones de Servicio, 14 December 2006, C-217/05. 
antitrust regulation, since it is arguable that they do not determine their conduct on the market independently from the conduct of their principals. ${ }^{28}$ Nonetheless, the ECJ's ruling continues by stating that the term 'employee' must be construed on the basis of definitions provided under its jurisprudence on employment matters, which is centred on a much stricter definition. The exemption would only apply when 'the essential feature of that relationship is that for a certain period of time one person performs services for and under the direction of another person in return for which he receives remuneration.29 The need for 'direction of another person' recalls the employment law test of 'legal subordination' rather than the 'independence on the market' test of antitrust law mentioned above. A mere economic dependency would not likely be sufficient to meet the legal subordination test under the ECJ reasoning. Therefore, under this tight definition, the abovementioned categories of 'dependent' self-employed persons would not be classified as 'employees' and would therefore not be exempted from antitrust laws for the purpose of collective bargaining. According to the ECJ, only 'false' self-employed workers would be able to bargain with employees side-by-side and to benefit from cooperating with established labour unions. Genuine dependent self-employed workers, who are a significant component of the non-standard workforce, ${ }^{30}$ would be prevented from doing $\mathrm{so}^{31}$ even if their weaker status in labour markets is recognised under the national regulation. In the ECJ's perspective, this would likely also have

\footnotetext{
${ }^{28} \mathrm{~A}$ comparative analysis of the regulation on dependent self-employment is provided in the articles published in the (Winter 2010) 32 Comparative Labor Law \& Policy Journal and in A. Perulli, 'Subordinate, Autonomous and Economically Dependent Work: A Comparative Analysis of Selected European Countries' in G. Casale (ed.), The Employment Relationship A Comparative Overview (Geneva: ILO, 2011).

${ }^{29} \mathrm{ECJ}$, Allonby v Accrington and Rossendale College, 13 January 2004, C-256/01.

${ }^{30}$ Eurofound, Self-Employed or Not Self-Employed? Working Conditions of 'Economically Dependent Workers'. Background Paper (Dublin: Eurofound, 2013); OECD, OECD Employment Outlook (Paris: OECD, 2014).

${ }^{31}$ It is worth noting that, in the case at hand, the Court of Appeal of the Hague, called to assess whether the self-employed orchestra players could be exempted by competition law in the light of the ECJ decision in FNV Kunsten, eventually found that these workers could be regarded as false self-employed and therefore were entitled to collective bargaining. The matter, however, is far from being resolved in general terms both at the EU and national level; the same judgement of the Court of Appeal explicitly stated that it would not 'give judgment on the question of whether self-employed other than substitutes (such as self-employed workers without employees in general or working in another sector) must be regarded as "false self-employed" within the meaning referred to here'. The judgment, dated 1 September 2015, is available at http:// www.fim-musicians.org/wp-content/uploads/AF0905-1509-court-of-appeal-2015-09-01.pdf (accessed 28 March 2016).
} 
significant effects on their ability to go on strike, since this right is mainly seen as functional to collective bargaining in the Court's jurisprudence. ${ }^{32}$

This is only one of the examples showing that current standards of regulation of freedom of association and related collective rights are failing to keep pace with the growth of the non-standard workforce in modern labour markets. Some existing restrictions on these rights are also at odds with a significant legal development in the theoretical construction of collective rights that occurred in relatively recent times, namely their recognition as human rights under a growing body of international and national legal instruments and jurisprudence. For example, restricting access to the right to organise and bargain collectively to employees and to the 'false selfemployed' contradicts the full recognition of these rights as human rights as it does not make sense to preclude access to a human right on the basis of an individual's employment status. ${ }^{33}$ This contradiction is all the more evident for a right such as collective bargaining that has widely been recognised as an essential component of freedom of association. ${ }^{34}$ In the following sections, the nature of collective rights as human rights will first be briefly restated, showing how, as in the case of restrictions affecting dependent

${ }^{32}$ ECJ, International Transport Workers' Federation and Finnish Seamen's Union v Viking Line, 11 December 2007, C-438/05; ECJ, Laval v Svenska Byggnadsarbetareförbundet, Svenska Byggnadsarbetareförbundets avdelning 1, Byggettane e Svenska Elektrikerförbundet, 18 December 2007, C-341/05.

${ }^{33}$ The CEACR had firstly expressed concern over the case litigated in FNV Kunsten in Netherlands - CEACR, Observation, 2010 and Netherlands - CEACR, observation, 2008. In a very recent comment regarding antitrust restriction to collective bargaining of self-employed persons in Ireland, the CEACR, also referring to the ECJ judgment in FNV Kunsten, reiterated that 'the right to collective bargaining should also cover organizations representing the self-employed' and called the Government 'to hold consultations with all the parties concerned with the aim of limiting the restrictions to collective bargaining that have been created by the Competition Authority's decision, so as to ensure that self-employed workers may bargain collectively'; see Ireland - CEACR, observation, 2015. The rights to freedom of association and collective bargaining, enshrined in two of the Eight Fundamental Conventions of the International Labour Organisation are universal and applicable to all workers. According to the ILO Supervisory Bodies, these rights also apply to self-employed workers, see Turkey CEACR, observation, 2010; Senegal-CEACR, direct request, 2011. See also ILO, Freedom of Association. Digest of Decisions and Principles of the Freedom of Association Committee of the Governing Body of the ILO, 5th edn (revised) (Geneva: ILO, 2006) 53.

${ }^{34}$ See, for instance, European Court of Human Rights (ECtHR), Demir and Baykara $v$ Turkey, 12 November 2008, Application No. 34503/97 and other case law and references at n.37. See also the opinions of the ILO CFA in ILO (n.33) 177, restating that the 'right to bargain freely with employers with respect to conditions of work constitutes an essential element in freedom of association' 


\section{COLLECTIVE LABOUR RIGHTS AS HUMAN RIGHTS AND IMPLICATIONS FOR NON-STANDARD WORKERS}

In one of his last works Professor Hepple gave an account of the evolution of the right to strike from a tool in collective bargaining to a human right. ${ }^{35}$ This issue forms part of the general debate on the construction of labour rights as human rights ${ }^{36}$ and has gathered significant attention in connection with recent landmark decisions of supranational and national supreme courts. ${ }^{37}$ As already mentioned, this question is strongly interrelated with the issue of securing that non-standard workers can fully and effectively exercise freedom of association.

Indeed, categorising workers' collective rights as human rights must prompt a reflection on the legal restrictions posed to these rights. This is particularly true regarding the right to strike, whose exercise, as shown below, is often impaired

\footnotetext{
${ }^{35}$ B. Hepple (n.3). The same argument was held by S. Sciarra, "Heritage and Adjustment": Some Concluding Remarks' in B. Hepple, R. le Roux and S. Sciarra (n.3). See T. Novitz, International and European Protection of the Right to Strike: A Comparative Study of Standards Set by the International Labour Organization, the Council of Europe and the European Union (Oxford: Oxford University Press, 2003).

${ }^{36}$ Comprehensive contributions to this debate are provided in C. Fenwick and T. Novitz, Human Rights at Work: Perspectives on Law and Regulation (Oxford: Hart, 2010). See also D. Kolben, 'Labor Rights as Human Rights?' (2010) 50 Virginia International Law Review 450-84 and V. Mantouvalou, 'Labour Rights in the European Convention on Human Rights: An Intellectual Justification for an Integrated Approach to Interpretation' (2013) 13 Human Rights Law Review 529-55, also for a recollection of this debate.

${ }^{37}$ European Court of Human Rights (ECtHR), Demir and Baykara v Turkey (n.34); ECtHR, Enerji Yapi-Yol Sen v Turkey, 21 April 2009, Application No. 68959/01;ECtHR, Danilenkov and Others. v Russia, 10 December 2009, Application No. 67336/01; ECtHR, Sindicatul 'Păstorul cel Bun'v Romania, 31 January 2012, Application No. 2330/09; ECtHR, RMT v United Kingdom, 8 April 2014, Application No. 31054/10. Constitutional Court of South Africa, Bader Pop (pty) Ltd v NUNMSA, 2002 ILJ (South Africa) 104 (LAC); Supreme Court of Canada, Dunmore v Ontario (AG) [2001] 3 S.C.R. 1016, 2001 SCC 94; Supreme Court of Canada, Health Service and Support - Facilities Subsector Bargaining Assn. v British Columbia [2007] SCC 27; Supreme Court of Canada, Ontario $(A G) v$ Fraser [2011] SCC 20. On these decisions and their implications, see B. Langille, 'Can We Rely on the ILO?' (2007) 13 Canada Journal of Labour and Employment Law 273-300; J. Fudge, 'Constitutional Rights, Collective Bargaining and the Supreme Court of Canada: Retreat and Reversal in the Fraser Case' (2012) 41 ILJ 1-29; T. Novitz, 'The Internationally Recognized Right to Strike: A Past, Present, and Future Basis upon Which to Evaluate Remedies for Unlawful Collective Action?' (2014) 30 International Journal of Comparative Labour Law and Industrial Relations 357-79.
} 
in a way that is incompatible with its recognition as a human right. It goes without saying that this right, like any other right, including human rights, can be limited. Indeed, no legal system recognises an entirely unrestricted right to strike, even when it is protected at the constitutional level. ${ }^{38}$ Nonetheless, considering collective rights as human rights also calls for these restrictions be limited only to those strictly necessary in protecting other human rights. Allowing broader restrictions may indeed endanger not only the full exercise of freedom of association: a severely limited human right to collective bargaining and industrial action would imply tolerance for unnecessary limits to human rights and put in jeopardy, or at least water down, the entire human rights discourse. As already mentioned, reviewing current restrictions is also essential to ensure that the possibility of significantly exercising collective labour rights is granted to all workers, since existing limits to freedom of association, collective bargaining and industrial action may pose significant barriers for increasing portions of the workforce and in particular for non-standard workers.

There are compelling reasons that call for a joint analysis of the classification of labour, and in particular collective rights as human rights and the access of non-standard workers to those rights.

A rationale for approaching labour rights in connection with human rights lies with managerial prerogatives. ${ }^{39}$ In any jurisdiction, laws, customs and practice grant employers extensive rights over workers; these rights are enshrined in regulation that vest employers with an authority over their workers that goes beyond social norms and is also recognised from the legal standpoint. ${ }^{40}$ Such an authority may affect the workers' dignity as human beings and, therefore, its limitation and rationalisation is also relevant from the human rights' perspective. ${ }^{41}$ Non-standard workers are arguably exposed to some mechanisms that may magnify employers' managerial prerogatives

\footnotetext{
${ }^{38} \mathrm{On}$ the limitations in national constitutional traditions, see $\mathrm{H}$. Cheadle, 'Constitutionalising the Right to Strike' in B. Hepple, R. le Roux, S. Sciarra (n.3); a related analysis concerning international and regional systems is carried out by T. Novitz, 'The International and Regional Framework', ibid. A comprehensive comparative review of national regulations of the right to strike is contained in ILO, Background Document for the Tripartite Meeting on the Freedom of Association and Protection of the Right to Organise Convention, 1948 (No. 87), in Relation to the Right to Strike and the Modalities and Practices of Strike Action at National Level (Revised) (Geneva: ILO, 23-25 February 2015).

${ }^{39} \mathrm{~V}$. De Stefano, 'La protezione del diritto di sciopero nella dialettica tra corti e organi di supervisione internazionali’ (2014) 143 Giornale di Diritto del Lavoro e di Relazioni Industriali 461-94.

${ }^{40}$ See R. De Luca Tamajo, La Norma inderogabile nel diritto del lavoro (Napoli: Jovene, 1976); A. Supiot, Critique du droit du travail (Paris: PUF, 1994).

${ }^{41}$ See L. Mengoni, 'I poteri dell'imprenditore' in L. Mengoni (ed.), Diritto e valori (Bologna: il Mulino, 1985; the essay is dated 1975); H. Collins, 'Utility and Rights in Common Law Reasoning:
} 
such as 'implicit threat' ${ }^{42}$ as well as 'extended entry tournament' effects. ${ }^{43}$ Reinforcing instruments to counter this potential enhancement of managerial prerogatives is therefore essential to secure protection of their human dignity at the workplace. Since the rights to collective bargaining and action represent a chief instrument for limiting and rationalising managerial prerogatives ${ }^{44}$ granting access of non-standard workers to these rights is also the pivotal factor in providing effective safeguard of their human rights.

Therefore, the construction of collective rights as human rights can undoubtedly have a specific beneficial effect for non-standard workers that must be given adequate attention when reassessing restrictions on the exercise of freedom of association in order to keep pace with the growth of the non-standard workforce. In the following sections, I will highlight some of the areas in which this reassessment seems especially needed in light of what has been discussed so far. The focus will particularly be on the right to strike, since legal restrictions to this right have so many important practical consequences for nonstandard workers to indeed have more general implications, arguably also offering a positive answer to the question left unsolved by the European Court of Human Rights in the RMT case as to whether the right to strike must be considered an essential element in the protection of freedom of association.

\section{FRAGMENTED SOCIETIES AND COLLECTIVE RIGHTS: NON-STANDARD WORKERS, MINORITY UNIONS AND STRIKE BALLOTS}

Compelling arguments to justify the right to strike where presented by Professor Sir Otto Kahn-Freund ${ }^{45}$ in the 1970 s and recently re-examined by

Rebalancing Private Law through Constitutionalization, LSE Law, Society and Economy Working Papers 6/2007; O. De Schutter, 'Human Rights in Employment Relationships: Contracts as Power' in F. Dorssemont, K. Lörcher and I. Schömann (eds), The European Convention on Human Rights and the Employment Relation (Oxford: Hart Publishing, 2013).

${ }^{42}$ See Section 3 above.

${ }^{43} \mathrm{D}$. Marsden, "The Growth of Extended "Entry Tournaments" and the Decline of Institutionalised Occupational Labour Markets in Britain' in Lee and McCann (n.7), describes extended entry tournaments as mechanisms whereby workers are constrained to engage in several short-term and project-based work arrangements used by firms as screening processes before having the opportunity to be employed on a long-term basis, this also pertains to occupation and in sectors where access to stable employment was formerly more direct.

${ }^{44}$ See O. Kahn-Freund, Labour and the Law (London: Stevens, 1972); S. Liebman, Individuale e collettivo nel contratto di lavoro (Milano: Giuffrè, 1993).

${ }^{45}$ O. Kahn-Freund and B. Hepple, Laws against Strikes (London: Fabian Research Series 305, 1972). 
Bob Hepple ${ }^{46}$ in the light of developments that have occurred since those arguments were first outlined. In Professor Hepple's analysis, a main development is globalisation that, together with freedom of movement of capital, magnifies employers' managerial prerogatives by allowing them to delocalise production.

Besides globalisation, on which I will return in Section 6 below, the world of work has endured other profound transformations that have also driven changes in other sectors of society. It is an obvious statement that societies are more complex than they were when some of the existing regulation of unionism and collective action were devised. It is not necessary to entirely subscribe to Guy Standing's argument that the growth of non-standard work generated a class, 'the Precariat', which is structurally separated and distinct from other sectors of the workforce, ${ }^{47}$ to recognise that the world of work, particularly in industrialised countries, is now more composite and fragmented than four or more decades ago. This also calls into question some existing forms of labour representation. Most representative unions and union confederations remain pivotal institutions within labour markets and are fundamental in promoting solidarity across different sectors of the workforce and combating inequality. ${ }^{48}$ However, more complexities in societies and in the world of work may also result in the emergence of minority unions or other more 'fluid' forms of workers' movements ${ }^{49}$ : this process may very well also regard non-standard workers, given their abovementioned possible reluctance to join traditional unions or difficulties doing so.

Reassessing some of the existing regulation on unionisation and collective action may therefore be necessary to better govern labour relations and avoid more severe social unrest. Several commentators have underlined how high numbers of non-standard workers, the fragmentation of the

${ }^{46}$ B. Hepple (n.3).

${ }^{47}$ See G. Standing, The Precariat: The New Dangerous Class (London: Bloomsbury, 2011).

${ }^{48}$ See M. Ebisui, 'Non-Standard Workers: Good Practices of Social Dialogue and Collective Bargaining, Dialogue Working Paper No. 36 (Geneva: ILO, 2012); S. Hayter and M. Ebisui (n.21); E. Xhafa, 'Collective Bargaining and Non-Standard Forms of Employment: Practices That Reduce Vulnerability and Ensure Work Is Decent', INWORK Labour Relations and Collective Bargaining, Issue Brief No. 2 (Geneva: ILO, 2015); S. Hayter, 'Unions and Collective Bargaining' in J. Berg (ed.), Labour Markets Institutions and Inequality: Building Just Societies in the 21 ${ }^{\text {st }}$ Century (Cheltenham: Edward Elgar, 2015).

${ }^{49}$ See, for instance, S. Routh, 'Informal Workers' Aggregation and Law' (2016) 17 Theoretical Inquiries in Law, 283-320 and, for an account of new forms of collective protests, also involving citizens beyond workers, such as the 'flashmob', see E. Ales, 'Lo sciopero (nei servizi pubblici) in Germania: uno sguardo critico dall'Italia' WP CSDLE 'Massimo D'Antona'. INT 117/2015. 
workforce through subcontracting, and its link with rivalry and violence between different unions, had a part in the notorious event in Marikana. ${ }^{50}$ It would certainly be an exaggeration to suggest that these tragic incidents are an inevitable outcome of the so-called fissurisation of the workplace and the deriving limitations of workers' representation. ${ }^{51}$ Nonetheless, these phenomena call for action to prevent and solve inter-union, or other intraworkforce, conflicts that may occur as a consequence of fissuring practices.

The recognition of collective labour rights as human rights should play a prominent role in these efforts. Protection of human rights is complete and effective only if those rights are also granted and safeguarded for minorities; the regulation of collective bargaining and collective action should not be so restrictive to irremediably impede minority unions to accede to those rights. ${ }^{52}$ Most importantly, what should also be verified is whether existing restrictions impose disproportionate hurdles for non-standard workers in order to effectively enjoy freedom of association.

A first limitation that may pose excessive burden to some non-standard workers is strike ballots. Strike ballots normally require the presence of well-organised unions and a significant union density within the relevant bargaining unit. Moreover, the relevant regulations may also require unions to provide detailed information on the procedure followed, the electorate, the turnout, etc. All this can prove extremely burdensome when material numbers of non-standard workers may be interested in striking. Indeed, ballot regulation may impose material obstacles for non-unionised workers to

${ }^{50} \mathrm{C}$. Chinguno, 'Marikana: Fragmentation, Precariousness, Strike Violence and Solidarity' (2013) 40 Review of African Political Economy 639-46; K. Forrest, 'Marikana Was Not Just About Migrant Labour', Mail \& Guardian, 13 September 2013, available at http://mg.co.za/ article/2013-09-13-00-marikana-was-not-just-about-migrant-labour (accessed 28 March 2015). On the Marikana massacre, more in general, see contributions in B. Hepple, R. le Roux and S. Sciarra (n.3). See also T. Ngcukaitobi, 'Strike Law, Structural Violence and Inequality in the Platinum Hills of Marikana' (2013) 34 ILJ (South Africa) 836-58.

${ }^{51}$ See D. Weil, The Fissured Workplace: Why Work Became So Bad for So Many and What Can Be Done to Improve It (Cambridge, MA: Harvard University Press, 2014). On the disintegration of vertical firms and its effects on workplaces and labour regulation, see the landmark study of H. Collins, 'Independent Contractors and the Challenge of Vertical Disintegration' (1990) 10 Oxford Journal of Legal Studies 353-80.

${ }^{52}$ According to the ILO CEACR, the grant of specific advantages and rights to most representative unions is compatible with the principles enshrined in the Freedom of Association and Protection of the Right to Organise Convention, 1948 (No. 87) provided that this does not entail 'the effect of depriving those trade unions that are not recognized as being amongst the most representative of the essential means of defending the occupational interests of their members': see, ILO, CEACR (n.14) 36. 
initiate a strike. ${ }^{53}$ Since, as discussed above, unionisation of non-standard workers can be difficult or scarce, regulation mandating strike ballots can disproportionately affect non-standard workers. This requires attentive scrutiny when assessing compliance of this regulation with the principles of freedom of association. Moreover, organising strike ballots and providing precise information on the relevant workforce can become excessively onerous in relation to very 'casualised' workplaces. Highly volatile nonstandard work arrangements such as job-on-call, zero-hour contracts and marginal part-time work, together with extremely flexible schedules, are increasingly spreading in developed countries. ${ }^{54}$ This renders the presence within a particular work unit unstable and workers more detached from their workplaces and from existing workers' representatives. Workforces are more scalable and therefore more variable: in these circumstances, organising a ballot and providing accurate information about it could prove practically impossible.

This could firstly impose excessive hardship in organising a lawful strike, one that would not be compatible with the recognition of the right to strike as a human right, unless it could be proven that such restrictions were essential in protecting other fundamental rights..$^{55}$ Importantly, in the European legal context, this conclusion is not contradicted by the ECtHR's decision in the $R M T$ case, concerning the UK legislation on strike ballots. In $R M T$, the Court did not find this legislation in violation of freedom of association since the workers eventually managed to organise a successful strike based on the consideration that 'the Court can only examine complaints in light of their concrete facts. ${ }^{56} \mathrm{~A}$ violation of freedom of association under article 11 of the ECHR can then still be found if a significant number of the workers

\footnotetext{
${ }^{53}$ See L. Corazza and E. Fergus, 'Representativeness and the Legitimacy of Bargaining Agents' in B. Hepple, R. le Roux, S. Sciarra (n.3).

${ }^{54} \mathrm{~V}$. De Stefano, 'Casual Work beyond Casual Work in the EU: The Underground Casualization of the European Workforce and What to Do about It' (2016) 7 European Labour Law Journal 421-42. J. Messenger and P. Wallot (n.19).

${ }^{55}$ In this respect, it is also worth noting that the ILO CEACR recently expressed serious concern over the tightening of strike ballot requirements under the proposed Trade Union Bill in the UK, also because some of the services that would be affected by the strictest requirements in terms of strike ballots would not fall within the Committee's 'understanding of essential services in the strict sense of the term [...] in which restrictions on industrial action are permissible', namely only those services 'the interruption of which would endanger the life, personal safety or health of the whole of part of the population' See United Kingdom - CEACR, observation, 2015, and, for the definition of essential services ILO, CEACR (n.14) 53.

${ }^{56}$ For a critical review of this decision, see A. Bogg and K. D. Ewing, 'The Implications of the RMT Case' (2014) 43 ILJ 221-52.
} 
were engaged through casual arrangements that make the workforce so unstable that it would impossible or particularly difficult to organise a ballot.

Moreover, excessively restrictive regulation could deprive workers of access to the ability to strike lawfully, encouraging wildcat strikes and illegal forms of collective action. The result might be increasing tension at the workplace and also within the workforce and prove far more disruptive for societies at large than less restrictive strike laws. In such a case, removing or relieving those hurdles would not only be just and in line with the recognition of the right to strike as a human right but might also prevent unfairness from stirring unnecessary conflicts. ${ }^{57}$

\section{PROMOTING SOLIDARITY: SECONDARY ACTION, FISSURED WORKPLACES AND NON-STANDARD WORKERS}

Fostering solidarity among different workers and trying to counter the most detrimental effects of workforce's fragmentation is another way to prevent conflicts. For instance, recently the US National Labour Relations Board refined its joint-employment status making it easier for workers of subcontractors to be recognised as employed by the principal company jointly with the subcontractor for the purpose of collective rights (Browning-Ferris Industries of California, Inc. ..$^{58}$ This decision, manifestly adopted 'to better effectuate the purposes of the Act in the current economic landscape', can prove to be a landmark also for other future decisions on other fissuring practices such as franchising. Another recent decision of the NLRB ${ }^{59}$ has removed the requirement of having the employer's consent in order to include both employees employed solely by the user firm and jointly employed employees in a same bargaining unit. This has been a crucial decision to ensure that agency workers have an effective right to organise together with workers of user firms.

Reviewing the standards for secondary actions and sympathy strike may also be essential to foster solidarity and prevent conflicts. Existing restriction

\footnotetext{
${ }^{57} \mathrm{On}$ the risk that restrictive laws on strikes may prompt unlawful collective action and cause more severe unrest than the one they are meant to avoid see M. Ford and T. Novitz, 'An Absence of Fairness... Restrictions on Industrial Action and Protest in the Trade Union Bill 2015' (2015) 44 ILJ 522-50.

${ }^{58}$ NLRB, Browning-Ferris Industries of California, Inc., 362 NLRB No. 186 (27 August 2015) Case 32-RC-109684.

${ }^{59}$ NLRB, Miller \& Anderson, Inc., 364 NLRB No. 39 (7 July 2016) Case No. 05-RC-079249.
} 
to these forms of industrial action may fail to keep pace with the changes in workplace's organisations driven by vertical disintegration of businesses, and related fragmentation practices such as subcontracting. The Italian case is an example in this respect: secondary action in Italy is still criminally sanctioned under an article of the Penal Code enacted in 1930 by the Fascist Regime. In 1962, the Constitutional Court declared that sympathy strikes are legitimate when secondary actions are adopted in support of a pending primary strike carried out by workers in the same sector, when the relevant workers' interests are akin to such an extent that it is presumable that these interests would be frustrated in lack of a joint effort ${ }^{60}$ It is evident that any such standard is no longer suited to operate in a modern labour market and can be particularly detrimental to non-standard workers. For instance, the workers of a principal business would be unable to go on strike in support of the workers of a subcontractor unless these latter workers went on strike in the first place. ${ }^{61}$ If the subcontractor's workers were scarcely unionised or reluctant to call an industrial action in fear of retaliation from the subcontractor or the principal business, the current standard would impede action from other workers. Moreover, in the current economic landscape of vertical disintegration, being able to act in secondary strikes only to support workers in the same sector is far too limited since the production may be fissured among companies of several sectors. This is particularly true in the Italian industrial relation system, where a sector is normally defined by making reference to the national collective bargaining agreement applied. As several of such agreements may apply in the same production chain, the current standard for sympathy strike would prevent secondary action to a much greater extent than in the 1960s, neutralising solidarity in favour of the weakest parts of the workforce, in particular non-standard workers.

In the light of the increasing fissurisation of workplaces, even the ECtHR's decision in $R M T$, deeming a total ban on secondary action compatible with Article 11 of the European Convention on Human Rights could be called into question. Indeed, by distinguishing between primary and secondary elements of freedom of association when assessing the legitimacy of such a ban, the Court seems to have overlooked the severe hardships that an

${ }^{60}$ Corte Costituzionale, 28 Dicembre 1962, no. 123 in Foro Italiano, 1963, I, c. 5.

${ }^{61}$ Also the French standard, set out by Cour de Cassation, Crim. of 12 Janvier 1971, D. 1971 129 , requires that a lawful primary strike be carried out to proceed with a secondary action. In Germany, as from 2007, the Bundesarbeitsgericht revised its previous position whereby solidarity strikes were considered unlawful since not directed against a potential collective bargaining counterpart (BAG 19.06.2007,1 AZR 396/06). See E. Ales (n.49). 
increasing number of workers, and notably non-standard workers, have to face in joining unions and exerting their collective rights at the present time. In such circumstances, a ban on secondary action could go as far as nullifying the only realistic way of providing those workers with a meaningful voice or bargaining power. Therefore, the distinction between primary and secondary elements of freedom of association appears to be artificial in this regard and, as already mentioned, it could disproportionately affect the most vulnerable sectors of the workforce. Once again, the right to strike can act as paradigm of the need to reconsider restrictions on the exercise of freedom of association taking into account the increasing relevance of nonstandard workers in modern labour markets.

The same or even worse problems regarding sympathy action could be faced when international supply chains are involved. Domestic standards for sympathy actions were chiefly devised before globalisation. ${ }^{62}$ As such, they could be ill-suited to serve in modern times: cross-border solidarity may be pivotal in supporting decent work standards in countries where weak labour organisation exist, ${ }^{63}$ also via action from stronger national labour movements. ${ }^{64}$ This is all the more relevant when codes of conduct and other commitments are in place that are not legally binding or easily actionable in court. Less restrictive secondary action standards would enable workers to better monitor the compliance with these commitments and, where necessary, sanction their 'breach' by means of industrial disputes and collective actions. This would enhance enforcement of the commitments of businesses that may otherwise remain merely voluntary in nature and may be pivotal in securing compliance with other fundamental human rights' objectives such as the effective ban on discrimination and child and forced labour. Freedom of association and collective rights might therefore also be enabling rights on a cross-border basis: reassessment and revision of

\footnotetext{
${ }^{62}$ See, however, Lord Wedderburn, 'Multi-National Enterprise and National Labour Law' (1972) 1 ILJ 12-9 and O. Kahn-Freund, 'A Lawyer's Reflections on Multinational Corporations' in (1972) 14 Journal of Industrial Relations 351-60.

${ }^{63}$ In this respect, for further references and a discussion of a potential role of the EU in the protection of secondary action, see P. Germanotta and T. Novitz, 'Globalisation and the Right to Strike:The Case for European Level Protection of Secondary Action' (2002) 18 International Journal of Comparative Labour Law and Industrial Relations 67-82; for a recent analysis that takes into account the developments at the EU level in this regard, see F. De Witte, Justice in the EU: The Emergence of Transnational Solidarity (Oxford: Oxford University Press).

${ }^{64}$ On transnational collective action, see W. Warneck, 'Transnational Collective Action - Already a Reality?' in F. Dorssemont, T. Jaspers and A. van Hoek (eds), Cross-Border Collective Actions in Europe: A Legal Challenge (Antwerpen: Intersentia, 2007).
} 
existing standards on solidarity actions, conceived in an era when international business exchanges were far more limited, seems therefore essential to keep pace with the modern reality of the global economy.

\section{THE DISTINCTION BETWEEN POLITICALAND ECONOMIC STRIKES:THE SHIFT FROM 'JOB-BASED-PROTECTION'TO 'MARKET-BASED-PROTECTION' AND COLLECTIVE RIGHTS}

A further limitation in strike laws that was already described as inadequate almost 25 years ago ${ }^{65}$ and that in the current world of work is becoming increasingly arbitrary is the distinction between economic and political strikes. It has recently been shown how a vast amount of collective actions were called in Europe in recent years to protest against austerity measures. ${ }^{66}$ This is one of the areas in which the boundaries between economic and political strikes are most blurred. Even if one assumes the phase of protests against these measure to be only contingent, the distinction between economic and political industrial action will likely blur in the future due to more structural trends in the labour market.

It is almost commonplace that the model of job-for-life model is receding in almost all sectors and occupations. At the same time, mainstream policy narratives have long been advocating substituting 'job-based-protection' for 'market-based-protection', namely a system of protection centred on workers' employability on the market and supported by unemployment benefits and active labour market policies to replace systems based on job stability. ${ }^{67}$ Without entering the debate on the opportunity and risks connected to these policies, if this is the scenario we are moving towards, the centre of protection would shift from the enterprise to labour markets as a whole. As Professor Silvana Sciarra recently pointed out, strikes are a fundamental means for workers to exercise their social power, ${ }^{68}$ if the pivot of labour protection shifts, industrial conflict would accordingly need to re-shift. In such a situation, if strikes were to be restricted as only a means of collective bargaining and individual workplaces' issues, the workers' power to

${ }^{65}$ Lord Wedderburn, 'The Right to Strike: Is there a European Standard?' in Lord Wedderburn (ed.), Employment Rights in Britain and Europe: Selected Papers (London: Lawrence \& Wishart, 1991).

${ }^{66}$ G. Orlandini, 'Political Strikes' in B. Hepple, R. le Roux and S. Sciarra (n.3).

${ }^{67}$ For a critical analysis of these narratives and for further references, see V. De Stefano (n.18).

${ }^{68}$ S. Sciarra (n.35). 
influence labour protections and overall policies would be severely curtailed. Consequently, it would prevent them from resorting to a fundamental instrument of workers' voice to influence policies that would affect their labour and social rights. Once again, since non-standard workers are normally more detached from their employers and mobile in labour markets, they would be the ones bearing most of the brunt of these developments.

\section{CONCLUSIONS}

This article has argued that some existing restrictions to freedom of association and collective rights are failing to keep pace with the growth of nonstandard workers experienced in many labour markets in recent years and that these restrictions need to be revised. It has been argued that advocating this revision does not imply subscribing to the view that the SER is irreversibly disappearing in industrialised economies or that it is no longer suitable to serve as a fundamental benchmark of employment regulation. Instead, what has been argued is that regulation was endogenous to the increase of non-standard work. In this respect, some existing collective labour regulations are prominent examples in this respect since they may impose obstacles that disproportionately affect, or prevent, the exercise of collective rights by non-standard workers and therefore provide undue incentives to resort to non-standard work arrangements. Several of these restrictions have been examined, such as antitrust standards that prevent some nonstandard workers from bargaining collectively, regulation of strike ballots, limitations of secondary industrial action and the distinction between political and economic strikes. A revision of these restrictions has been advocated to keep pace with the increasing spread of the non-standard workforce and the issues that it poses to existing labour market institutions. In doing so, this article has moved from the classification of labour rights, and in particular the right to strike, as human rights, a perspective adopted by many courts and scholars in recent times. ${ }^{69}$ It has been argued that this classification calls for a revision of existing restrictions and limits to collective rights to ensure that they are compatible with a human rights approach. In this regard, it has also been argued that the human rights perspective is pivotal to ensure that the weakest parts of the workforce, and especially non-standard workers, who may be particularly subject to the employers' managerial prerogatives,

${ }^{69}$ See $\mathrm{n} .36$ and n.37. 
are not denied effective access to fundamental labour rights and protection of human dignity at the workplace. Indeed, access to collective rights can be barred not only as a matter of fact, and attention should also be paid to how to remove or reduce practical obstacles in this regard, but also as a consequence of legal regulations that are increasingly outmoded in the current economic landscape. It has also been argued that removing legal and practical barriers would not only enhance fairness in labour markets but also remove reasons of more bitter frictions and risks of disruptive conflicts. In this perspective, collective rights recognised and enforced as human rights would also ultimately contribute to underpinning the rule of law, playing an important role in building more just and democratic societies in these times of globalisation. 